\title{
UPAYA PENINGKATAN KOMITMEN KERJA GURU BIDANG STUDI
}

\author{
Mustaghfiroh \\ Achmad Supriyanto \\ Agus Timan \\ Universitas Negeri Malang, Jl. Semarang 5 Malang 65I45 \\ Email: mustaghfiroh0I@gmail.com \\ aspriess@gmail.com \\ agus.timan.fip@um.ac.id
}

\begin{abstract}
The aims of this article is to determine the causal factors and also the impacts caused by the low commitment of teachers in the field of study at Riyadlul Qur'an Vocational High School and that strategies can be found to solve the problem. This study uses a descriptive qualitative research design by revealing data and facts in the field. Data collection techniques used in this study are analysis documents related to the presence of teachers, conducting interviews with related parties, and conducting observations directly related to teacher attendance and teacher return. In this study, the authors used a problem tree diagram technique to analyze problems, analyze the causes of problems and also analyze the impact caused by these problems. The results of this study indicate that the low commitment of teacher work at Riyadlul Quran Vocational High School caused by; (I) motivation of teacher work is low, (2) applicable school regulations are not implemented optimally, and (3) lack of supervision by the principal.
\end{abstract} Keywords: Work Commitment, Teacher, Tree Diagram Technique.

Abstrak: Penulisan artikel ini bertujuan untuk mengetahui faktor-faktor penyebab dan juga dampak-dampak yang ditimbulkan dari rendahnya komitmen kerja guru bidang studi di SMK Riyadlul Qur'an sehingga dapat ditemukan strategi penyelesaian masalah tersebut. Penelitian ini menggunakan rancangan penelitian deskriptif kualitatif dengan mengungkapkan data dan fakta yang ada di lapangan. Teknik pengumpulan data yang digunakan dalam penelitian ini adalah dokumen analisis terkait kehadiran guru, melakukan wawancara dengan pihak terkait, serta melakukan observasi secara langsung terkait kehadiran guru dan kepulangan guru. Dalam penelitian ini, penulis menggunakan teknik diagram pohon masalah untuk menganalisis masalah, menganalisis faktor penyebab masalah dan juga menganalisis dampak yang ditimbulkan oleh masalah tersebut. Hasil penelitian ini menunjukkan bahwa rendahnya komitmen kerja guru di SMK Riyadlul Qur'an disebabkan oleh; (I) motivasi kerja guru rendah, (2) peraturan sekolah yang berlaku tidak diterapkan secara maksimal, dan (3) kurangnya pengawasan kepala sekolah. Kata kunci: Komitmen Kerja, Guru Bidang Studi, Teknik Diagram Pohon.

\section{PENDAHULUAN}

Masalah mutu pendidikan adalah masalah yang sedang hangat-hangatnya dalam dunia pendidikan kita, terutama berkaitan dengan rendahnya mutu pendidikan yang ada di setiap jenjang pendidikan di Indonesia terutama dalam pendidikan dasar dan pedidikan menengah. Pengelolaan pendidikan dengan menciptakan lingkungan belajar yang kondusif secara berkelanjutan merupakan salah satu uapaya peningkatan mutu pendidikan di suatu satuan pendidikan. Pengelolaan pendidikan dalam hal ini berkaitan dengan komitmen dalam organisasi. Komitmen organisasi adalah suatu hal yang sangat penting yang harus ada dalam sebuah organisasi. Menurut Greenberg \& Robert (2003) komitmen organisasi adalah suatu bentuk keterlibatan karyawan dalam organisasi yang digelutinya dan berkeinginan untuk menjadi 
anggotanya, dimana terdapat kesetiaan dan kesediaan karyawan untuk kesukarelaan dalam bekerja dengan maksimal di organisasi tempat karyawan tersebut bekerja. Sedangkan menurut Luthans (2006), komitmen organisasi merupakan keinginan seseorang untuk tetap bertahan disuatu organisasi tertentu dan mempunyai keinginan untuk mewujudkan tujuan organisasi tersebut.

Komitmen organisasi diperlukan dalam organisasi pendidikan karena seorang guru yang memiliki komitmen tinggi pada organisasi sekolah akan cenderung memiliki sikap yang profesional dan menjujung tinggi nilai-nilai yang telah disepakati dalam sebuah organisasi. Sebagai bentuk keterikatan seorang guru dengan organisasi tertentu, maka ia akan mempunyai sikap, perasaan, dan pandangan tertentu tentang kondisi lingkungan organisasi. Kondisi ini akan membentuk sikap, perasaan dan persepsi tentang kondisi lingkungan organisasi, baik dalam bentuk kegiatan organisasi, nilai maupun norma yang berlaku dalam organisasi. Menurut Wibowo (dalam Susana, 2018) komitmen organisasi memiliki beberapa komponen, diantaranya adalah affectif commitment, normative commitment dan continuance commitment, dan masing-masing tipe komitmen tersebut dipengaruhi oleh faktor yang berbeda-beda. Affectif commitment dipengaruhi oleh berbagai karakteristik personal seperti kepribadian, dan pengalaman kerja sebelumnya. Sedangkan normative commitment dipengaruhi oleh proses sosialisasi yang mencerminkan keyakinan pekerja tentang apa yang seharusnya diterima sebagai imbalan atas apa yang telah mereka lakukan terhadap organisasi. Dan, continuance commitment dipengaruhi oleh kemauan dari individu itu sendiri untuk tetap bertahan dalam suatu organisasi dikarenakan kurangnya alternatif pekerjaan lain.

Komitmen kerja adalah kesanggupan seseorang untuk mewujudkan dan melakukan pencapaian tujuan organisasi secara umum (Hasibuan, 2005). Komitmen kerja guru yang tinggi sangatlah diperlukan dalam sebuah organisasi sekolah, karena terciptanya komitmen yang tinggi akan mempengaruhi situasi kerja yang profesional dan sesuai apa yang diharapkan. Salah satu cara untuk mengukur keberhasilan pendidikan nasional dalam mengembangkan kualitas peserta didik adalah dengan mengukur kualitas para pengajarnya. Keberhasilan peserta didik adalah bergantung kepada kualitas para pengajarnya. Karena pendidik merupakan pihak yang paling banyak bersentuhan langsung dengan siswa dalam proses pembelajaran di sekolah. Berdasarkan pendapat-pendapat diatas dapat disimpulkan bahwa komitmen kerja guru dalam suatu organisasi sekolah adalah keinginan guru untuk mempertahankan keanggotaannya dan turut bersedia berusaha untuk pencapaian tujuan organisasi dan juga kualitas pendidikan yang lebih baik untuk kedepannya.

Keberhasilan seorang guru banyak ditentukan oleh tingkat kompetensi, profesionalisme dan juga komitmen terhadap bidang yang ditekuninya. Komitmen seseorang terhadap organisasi tempat dia bekerja menunjukkan suatu upaya dari seseorang untuk ikut terlibat dalam mewujudkan visi misi organisasi tersebut. Srinalina (20I5) berpendapat bahwa kinerja guru pada dasarnya adalah suatu kinerja atau unjuk kerja yang dilakukan oleh seorang guru dalam melaksanakan tugas sebagai seorang pendidik. Oleh karena itu, sudah seharusya seorang guru memiliki kinerja yang optimal dalam rangka mewujudkan organisasi sekolah yang yang berkualitas dan juga berintegritas tinggi. Dalam hal ini guru harus mempunyai komitmen kepada peserta didik dan juga proses belajarnya. Artinya, komitemen tertinggi guru adalah untuk kepentinyan peserta didik. Selain itu, guru harus juga menguasai secara mendalam bahan dan materi ajar yang akan dijarakan kepada peserta didik. Guru juga harus juga ikut bertanggung jawab terhadap hasil belajar siswa mulai dari pengamatan dalam perilaku siswa sampai tes akhir dalam suatu pembelajaran. Serta, guru juga harus mampu berfikir secara sistematis tentang apa yang telah dilakukannya dan belajar dari pengalaman terdahulu dan juga sudah seyogyanya seorang guru menjadi bagian dari masyarakat belajar dalam lingkungan profesinya (Srinalina, 20I5). 


\section{METODE}

Penelitian ini menggunakan rancangan penelitian deskriptif kualitatif dengan mengungkapkan data dan fakta yang ada di lapangan. Penelitian ini bertujuan untuk mengetahui faktor-faktor penyebab dan dampak yang ditimbulkan dari rendahnya komitmen kerja guru SMK Riyadlul Qur'an dan juga strategi penyelesaian masalah tersebut. Teknik pengumpulan data yang digunakan dalam penelitian ini adalah dokumen analisis terkait rekap daftar hadir guru di TU dan daftar hadir guru di kelas, melakukan wawancara dengan pihak terkait, seperti kepala sekolah, guru, dan juga siswa, serta melakukan observasi secara langsung terkait kehadiran guru dan kepulangan guru.

\section{HASIL DAN PEMBAHASAN}

Dalam penelitian ini, penulis menganalisis masalah di sekolah menggunakan teknik analisis diagram pohon masalah (tree diagram) atau sering juga disebut diagram sistematik, analisis pohon, pohon analitis, atau diagram hirarkhi. Menurut Sutjiaji (2009) diagram pohon adalah suatu bentuk diagram yang dirancang secara detail dan memiliki hubungan satu sama lain. Diagram pohon dibuat dengan tujuan untuk menemukan hasil akhir dengan menelusuri kembali secara detail bagaimana hasil akhir tersebut dapat ditemukan. Dalam hal ini, dapat dikatakan bahwa diagram pohon dapat menjelaskan secara detail apa yang kita butuhkan dan apa pula hasil akhir yang didapatkan, sehingga kita dapat melakukan hal tersebut dengan cara paling efisien agar mendapatkan hasil yang kita inginkan.

Diagram pohon tidak hanya dapat digunakan untuk menganalsis satu kasus, melainkan dapat juga digunakan untuk mengalaisis beberapa kasus yang saling berhubungan. Seperti namanya, diagram pohon berbentuk seperti pohon yang memiliki satu batang dahan yang mencabang enjadi dua atau lebih. Begitupun juga dengan permasalahan yang akan dianalisis menggunakan diagram pohon, yaitu terdiri dari satu satu kategori besar yang kemudian dibagikan menjadi beberapa cabang untuk lebih terperinci dan lebih detail. Diagram pohon dapat membantu kita untuk menyederhanakan suatu masalah yang kompleks dan mempermudah kita untuk mendapatkan gambaran pada suatu permasalahan yang dihadapi. Menurut Dale (dalam Nasution 2015: 146) diagram pohon masalah merupakan alat yang berguna bagi manajer puncak dan manajer menengah untuk membuat rencana perbaikan proses berdasarkan input dari pelanggan. Dengan menyatakan tujuan utama tersebut menjadi sasaran antara dan tugas yang perlu dilakukan.

Menurut Azizah, dkk (20I4) pohon masalah (problem tree) adalah sebuah pendekatan atau metode yang digunakan untuk mengidentifikasi penyebab suatu masalah terjadi. Analisis pohon masalah dilakukan dengan membentuk pola pikir secara sistematis tentang komponen sebab akibat yang berkaitan dengan masalah yang sedang diteliti. Pohon masalah memiliki 3 bagian, yaitu bagian batang, bagian akar dan bagian cabang. Bagian batang perupakan gambaran dari masalah utama dan akar merupakan menyebabkan masalah inti terjadi, sedangkan cabang adalah dampaknya. Silverman (dalam Azizah dkk, 20l4) menyatakan bahwa istilah Diagram Tree diagram pohon masalah adalah suatu diagram yang sistematik yang dirancang untuk mengurutkan hubungan sebab-akibat.

Ada beberapa tujuan pembuatan pohon masalah, diantaranya adalah:

I. Membantu suatu organisasi dalam hal melakukan analilisis secra rinsi dalam mencari penyebab munculnya permasalahan utama.

2. Membantu suatu organisasi dalam menganalisis pengaruh atau dampak masalah utama bagi organisasi atau stakeholder lainnya.

3. Membantu suatu organisasi dalam mengilustrasikan hubungan antara masalah utama, penyebab masalah, dan dampaknya dalam suatu diagram.

4. Membantu suatu organisasi dalam mencari solusi atas masalah utamadengan melihat komponen sebab akibat dari suatu permaslaahan. 
Menurut penulis, dapat disimpulkan bahwa diagram pohon masalah (Tree Diagram) adalah suatu metode pemecahan masalah dengan mencari hubungan sebab-akibat dari suatu masalah. Sehingga dapat ditemukan teknik pemecahan masalah tersebut.

Pada bagian ini, penulis akan menganalisis data yang diperoleh selama penelitian di SMK Riyadlul Qur'an, dengan menggunakan teknik diagram pohon. Penulis menyampaikan uraian hasil penelitian mengenai rendahnya komitmen kerja beberapa guru bidang studi yang ada di Riyadlul Qur'an sehingga berdampak buruk terhadap kualitas hasil pembelajaran para peserta didik dan berdampak juga pada kualitas output/ lulusan sekolah. Rendahnya ketidakhadiran guru menjadi salah satu penyebab kecilnya angka partisipasi murid. Bahkan, ketidakhadiran guru menjadi alasan siswa tak bersekolah.dalam hal ini, ketidakhadiran guru mengindikasikan komitmen yang rendah yang dimiliki oleh seorang pengajar dalam menjalankan tugasnya. Berdasarkan analisa penulis, di SMK Riyadlul Qur'an ada beberapa guru yang tidak melaksanakan kewajibannya secara profesional seperti sering tidak masuk, tidak membuat rencana pembelajaran, serta acuh tak acuh terhadap program atau kegiatan yang dibuat oleh sekolah, sehingga kondisi institusi sekolah tidak kondusif. Namun sebaliknya ada juga guru atau staf yang bekerja dengan penuh semangat, disiplin dan selalu peka terhadap program atau kegiatan yang dibuat oleh sekolah. Fakta ini hanyalah sebagian dari kompleksitas permasalahan yang selalu dihadapi oleh kepala sekolah SMK Riyadlul Qur'an.

Menurut Saragih (20I2), permasalahan yang dialami guru menengah saat ini adalah lemahnya komitmen organisasi. Permasalahan seperti ini sebenarnya tidak hanya terjadi di sekolah menengah ini, melainkan hampir seluruh sekolah menengah yang lain juga memiliki masalah yang sama. Masalah seperti harus mendapat perhatian khusus dari pihak organsasi mapun dari pihak pemerintah. Apa yang menjadi penyebab terjadi kesenjangan seperti ini dan apa saja dampak yang ditimbulkan dari kesenjangan ini. Hal ini perlu kita telusuri dan dalami lebih lanjut.

Berikut adalah hasil analisa terhadap data mengenai faktor-faktor yang mempengaruhi dan juga dampak apa saja yang ditimbulkan dari rendahnya komitmen kerja guru di SMK Riyadlul Qur'an dengan menggunakan menggunakan teknik diagram pohon masalah (Tree Diagram), secara visual gambar berikut menunjukkan hasil identifikasi penyebab suatu masalah:

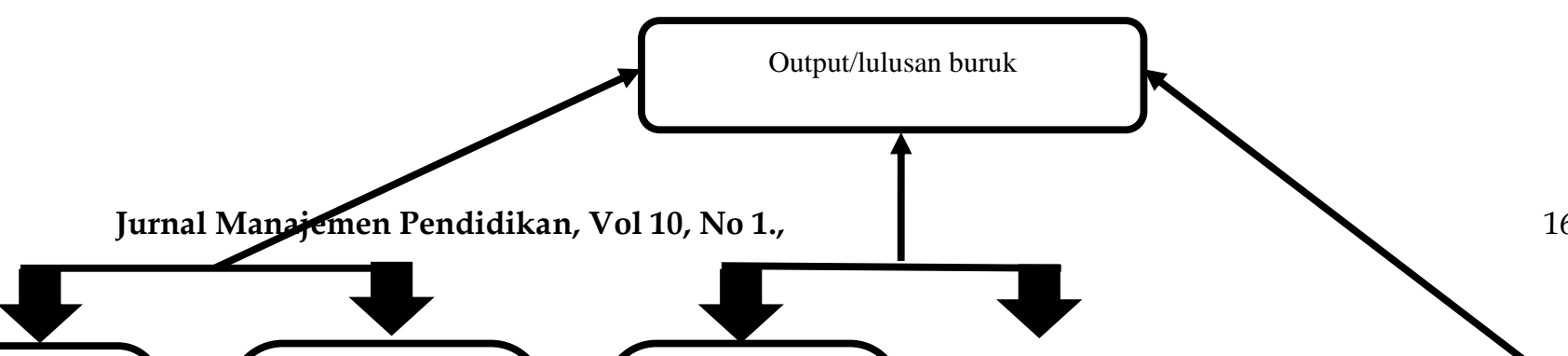




\section{Gambar 1. Diagram Pohon}

\section{Pembahasan}


Gejala-gejala yang ditimbulkan oleh komitmen kerja guru rendah antara lain adalah; (I) guru tidak bekerja dengan sungguh-sungguh, (2) guru tidak memberikan pelayanan terbaik, (3) tanggung jawab guru rendah, (4) tingkat kedisiplinan guru juga rendah, (5) guru sering izin tidak masuk dan (6) guru sering mengabaikan peraturan sekolah. Adapun, dampak negatif yang ditimbulkan dari kesenjangan ini, diantaranya adalah; (I) banyak jam kosong, (2) semangat belajar siswa turun, (3) hak siswa tidak terpenuhi dengan maksimal. Selain itu, terdapat juga dampak yang lebih rinci yang ditimbulkan dari dampak diatas. Banyaknya jam kosong dapat menyebabkan (I) siswa gaduh dikelas sehingga dapat mengganggu ketertiban kelas lain (2) siswa berkeliaran diluar sekolah yang berdampak terhadap pandangan buruk masyarakat tentang sekolah. Dan, semangat belajar siswa turun dapat menyebabkan (I) siswa akan malas mengikuti pelajaran di kelas karena tahu gurunya akan tak masuk, (2) prestasi siswa turun karena siswa jadi malas belajar. Serta hak siswa tidak terpenuhi dengan maksimal dalam proses pembelajaran berdampak pada materi pelajaran tidak tersampaikan dengan baik, sehingga materi yang didapatkan peserta didik tidak sesuai dengan harapan. Hal ini sangat merugikan pihak sekolah maupun orangtua peserta didik.

Masalah redahnya komitmen kerja guru bidang studi di SMK Riyadlul Qur'an disebabkan oleh beberapa faktor, diantaranya adalah (I) Motivasi kerja guru rendah, (2) Peraturan sekolah yang berlaku tidak diterapkan secara maksimal, dan (3) Kurangnya pengawasan kepala sekolah. Adapun rendahnya motivasi kerja guru disebabkan oleh dua faktor yaitu guru mempunyai pekerjaan lain dan jarak rumah guru kesekolah jauh. Sedangkan Peraturan sekolah yang berlaku tidak diterapkan secara maksimal disebabkan oleh guru sering mengabaikan peraturan sekolah. Serta Kurangnya pengawasan kepala sekolah disebabkan oleh kepala sekolah tidak pernah memberikan sanksi terhadap guru yang melanggar.

Pada uraian diatas sudah dijelaskana tentang dampak-dampak yang ditimbulkan dari masalah rendahnya komitmen kerja guru dan juga faktor-faktor penyebab timbulnya masalah tersebut. Maka strategi yang dapat diambil dalam upaya meningkatkan komitmen kerja guru bidang studi antara lain:

I. Kepala sekolah memberikan reward kepada guru yang disiplin dan mempunyai komitmen kerja tinggi, hal ini bertujuan untuk meningkatkan motivasi guru dalam menjalankan pekerjaannya.

2. Kepala sekolah bertindak tegas dan memberikan sanksi terhadap guru yang lalai atas tanggungjawabnya.

3. Sekolah menyediakan fingerprint.

4. Kepala sekolah lebih memperhatikan guru-guru yang kurang memiliki motivasi dalam mengajar dengan terus memberikan masukan, menegur setiap ada pelanggaran dalam hal kedisplinan.

5. Pihak sekolah mengusahakan dalam hal pemenuhan fasilitas media pembelajaran yang dibutuhkan oleh guru, guna untuk membangun motivasi guru dalam kegiatan pembelajaran dikelas.

\section{KESIMPULAN}

Guru merupakan orang yang sangat berpengaruh dalam proses pembelajaran. Terbentuknya komitmen kerja seorang guru dipengaruhi oleh beberapa faktor, diantaranya andalah faktor internal dan juga faktor eksternal. Faktor internal meliputi faktor yang berasal dari dalam diri seseorang, sedangkan faktor eksternal adalah faktor yang berasal dari lingkungan dalam organisasi maupun faktor diluar lingkungan organisasi. Komitmen seseorang terhadap organisasi tempat ia bekerja menunjukkan suatu daya dari seseorang dalam mengidentifikasi keterlibatan dalam organisasi tersebut.

Komitmen kerja guru yang tinggi sangatlah diperlukan dalam sebuah organisasi sekolah, karena terciptanya komitmen yang tinggi akan mempengaruhi situasi kerja yang profesional 
dan sesuai apa yang diharapkan. Salah satu cara untuk mengukur keberhasilan pendidikan nasional dalam mengembangkan kualitas peserta didik adalah dengan mengukur kualitas para pendidiknya. Keberhasilan peserta didik adalah bergantung kepada kualitas para pendidik. Karena pendidik merupakan pihak yang paling banyak bersentuhan langsung dengan siswa dalam proses pendidikan atau pembelajaran di lembaga pendidikan sekolah.

\section{DAFTAR RUJUKAN}

Azizah, dkk. 2014. Perencanaan Dan Evaluasipohon Masalah. Universitas Airlangga Surabaya.

Greenberg, J. \& Robert A. Baron. 2003. Behavior in Organization International Edition, New Jersey: Prentice Hall.

Hasibuan, S.P Malayu. 2005. Manajemen Sumber Daya Manusia. Edisi Revisi.jakarta : Bumi Aksara.

Luthans, Fred. 2006. Perilaku Organisasi. Edisi Sepuluh. PT. Andi: Yogyakarta.

Nasution, Nur. M. 20I5. Manajemen Mutu Terpadu (Total Quality Management). Bogor: Ghalia Indonesia.

Saragih, R. 2012. Pengaruh Persepsi Guru tentang Ke-pemimpinan Kepala Sekolah, Tim Kerja dan Ke-puasan Kerja terhadap Komimen Organisasi. Tesis tidak diterbitkan. Medan: Program Pascasarjana Universitas Negeri Medan.

Srinalina. 20I5. Faktor-Faktor Penyebab Rendahnya Kinerja Guru dan Korelasinya terhadap Pembinaan Siswa: Studi Kasus di Sman I Darul Imarah Aceh Besar. Jurnal Ilmiah Didaktika. I5 (2). 193-207.

Susana. 2018. Supervisi Akademik dan Komitmen Kerja Guru terhadap Kinerja Mengajar Guru. Jurnal Administrasi Pendidikan. 27 (I).

Sutjiaji, A, D. 2009. Aplikasi Network Pohon dalam Tree Diagram. Institut Teknologi Bandung. 